Sudut kemiringan (slope) dari garis lurus yang terbentuk memberikan nilai dugaan Z (Ricker, 1975).

Dengan menggunakan parameter pertumbuhan udang dogol yang telah dihitung $(K=1,52$ per tahun, $L_{\infty}=52,20 \mathrm{~mm}$ untuk udang betina serta $K=1,49$ per tahun dan $L O 0=41,50 \mathrm{~mm}$ untuk udang jantan) sebagai bahan masukan untuk membuat kurva hasil tangkap, diperoleh nilai dugaan $\mathrm{Z}$ untuk udang dogol betina sebagai 6,52 per tahun dan 8,68 per tahun untuk udang jantan (Gambar 3). Nilai dugaan laju kematian alamiah $(\mathrm{M})$ dihitung dengan menggunakan rumus empiris Pauly (1985) dan diperoleh nilai $M$ untuk udang dogol betina sebesar 2,01 per tahun dan untuk udang jantan sebesar 2,12 per tahun. Nilai dugaan laju kematian karena penangkapan (F) dihitung dengan menggunakan persamaan: $F=Z-M$ dan diperoleh hasil sebesar 4,51 per tahun untuk udang dogol betina serta 6,56 per tahun untuk udang dogol jantan.
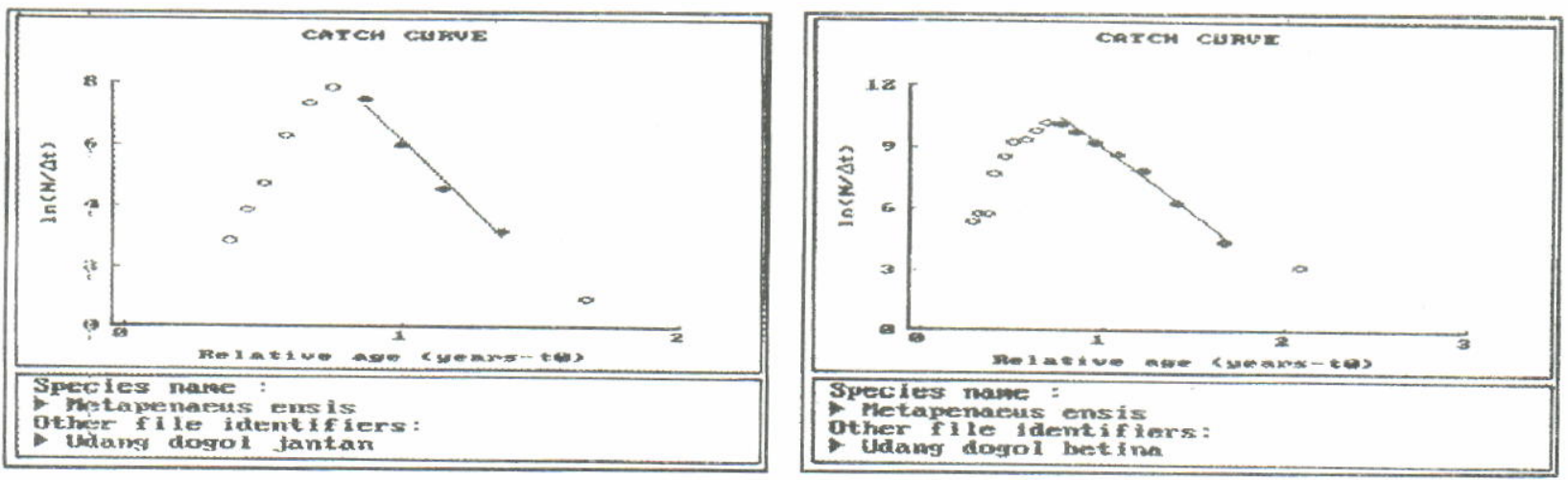

Gambar 3.

Nilai Z sebagai slope kurva hasil tangkapan udang dogol (Metapenaeus ensis de Haan) di perairan Cilacap dan sekitarnya.

Figure 3. $\quad Z$ value as curve slope of capture for endeavour shrimp (Metapenaeus ensis de Haan) in Cilacap and adjacent waters.

Laju kematian karena penangkapan (F) tergantung dan bervariasi menurut variasi upaya penangkapan (f) setiap tahunnya. Variasi laju kematian total ( $Z$ ) dari tahun ke tahun banyak ditentukan oleh laju kematian karena penangkapan $(F)$, karena laju kematian alamiah (M) tidak terlalu besar variasinya, apalagi kalau nilai $\mathrm{M}$ tersebut dapat dianggap tetap dari tahun ke tahun. Laju kematian karena penangkapan ( $F)$ udang dogol di perairan Cilacap dan sekitarnya adalah 6,56 per tahun untuk udang jantan dan 4,51 per tahun untuk udang betina.

Nilai $F$ tersebut relatif lebih tinggi bila dibandingkan dengan nilai $F$ dari hasil penelitian sebelumnya di perairan Cilacap yaitu sebesar 4,67 per tahun untuk udang dogol jantan dan 5,02 per tahun untuk udang betina (Suman, 1992), begitu juga bila dibandingkan dengan nilai $F$ udang dogol $(M$. affinis) di perairan Versoba, India yang sebesar 3,00 per tahun dan nilai $\mathrm{F}$ udang $M$. kutchensis di perairan Kandla, India yang sebesar 3,63 per tahun (Pauly et al., 1984). Fenomena ini menunjukkan betapa besar dan meningkatnya tekanan penangkapan (fishing pressure) terhadap stok udang dogol di perairan Cilacap dan sekitarnya.

Nilai dugaan $\mathrm{M}$ udang dogol relatif tidak berbeda jauh dengan nilai $M$ hasil penelitian terdahulu di perairan Cilacap yaitu 2,06 per tahun untuk udang betina dan 2,20 per tahun untuk udang jantan (Suman, 1992). Nilai M dari hasil penelitian ini juga tidak berbeda jauh bila dibandingkan dengan nilai $\mathrm{M}$ udang dogol (Metapenaeus affinis) dari perairan Versoba, India yang sebesar 2,29 per tahun dan udang Metapenaeus kutchensis dari perairan Kandla yang sekitar 2,20 per tahun (Pauly et al., 1984). Dengan demikian nilai $\mathbf{M}$ dari udang dogol di perairan Cilacap adalah berada dalam selang nilai-nilai $\mathrm{M}$ dari jenis-jenis udang Metapenaeus dan nilai laju kematian alamiah (M) biasanya dianggap tetap dari tahun ke tahun (Pauly et al., 1984).

\section{KESIMPULAN DAN SARAN}

1. Rata-rata ukuran pertama kali matang kelamin udang dogol di perairan Cilacap dan sekitarnya adalah pada panjang karapas $31,8 \mathrm{~mm}$. Musim pemijahan berlangsung sepanjang tahun dengan puncaknya bulan September.

2. Laju pertumbuhan (K) udang dogol di perairan Cilacap dan sekitarnya cukup cepat dan didapatkan laju pertumbuhan udang betina lebih cepat dari udang jantan. Laju kematian (Z, F, dan M) ditemui lebih tinggi pada udang jantan.

\section{DAFTAR PUSTAKA}

Dall, W., B. J. Hill, P. C. Rothlisberg, \& D. J. Staples. 1990. The biology of the penaeidae. In Blaxter, J. H. S \& A. J. Southward (eds.): Marine Biology Vol. 27, Academic Press. London, San Diego, New York, Boston, Sydney, Tokyo, Toronto: $489 p$. 
Gayanilo, F. C. Jr, P. Sparre, \& D. Pauly. 1993. The FISAT user's guide. FAO computerized information series fisheries. ICLARM-DIFMAR.

Gulland, J. A. 1983. Fish stock assessment. A manual of basic methods. John Wiley \& Sons. Chicester. $233 \mathrm{p}$.

Gunadi, W. 1981. Studi pendahuluan tentang penangkapan udang dengan trammel net di perairan Cilacap. Karya IImiah pada Fakultas Perikanan, IPB, Bogor: 68 hal.

Martosubroto, P. 1978. Musim pemijahan dan pertumbuhan udang jerbung (Penaeus merguiensis de Man) dan udang dogol (Metapenaeus ensis de Haan) di perairan Tanjung Krawang. Prosiding Seminar II Perikanan Udang: hal. 7-20.

Naamin, N. 1972. Perkembangan perikanan udang di perairan Cilacap dan Pangandaran. Laporan Penelitian Perikanan Laut No. 1: 59-79.

Naamin, N. 1978. Perkembangan perikanan udang di Indonesia. Prosiding Seminar II Perikanan Udang, hal.: 55-65.

Naamin, N. 1984. Dinamika populasi udang jerbung (Penaeus merguiensis de Man) di perairan Arafura dan alternatif pengelolaannya. Disertasi Doktor pada Fakultas Pasca Sarjana, IPB Bogor: 381 hal.

Pauly, D., J. Ingles \& R. Neal. 1984. Application to shrimp stocks of objective methods for the estimation of growth, mortality, and recruitment related parameters from length frequency data (ELEFAN I and II). In: Penaeid shrimp-their biology and management: 220-234. Fishing News Book Limited. Farnham-Surrey-England.

Pauly, D. 1985. Some simple methods for the assessment fish stocks. FAO Fish. Tech. Pap. (234), Roma.
Prawirodihardjo, S., A. Poernomo, S. Nurhamid, C. Siswono, \& J. Nugroho. 1975. Occurence and abundance of prawn seed at Jepara. Bull. Shrimp Cult. Res. Cent., I (1): 19-26.

Racek, A. A. \& W. Dall. 1965. Littoral penaeinae (Crustacea, Decapoda) from Northern Australia, New Guinea and adjacent waters. N. V. Nord Hollandsche Uitgeversmeart-Schappij, Amsterdam.

Ricker, W.E. 1975. Computation and interpretation of biological statistics of fish populations. Bull of the Fish. Res. Board of Canada. 191: 382 p.

Sparre, P. \& S. C. Venema. 1992. Introduction to tropical fish stock assessment. Part I. Manual. FAO Fish. Tech. Pap. No. 306/1.

Sudjastani, T. 1974. Dinamika populasi ikan kembung di Laut Jawa. Laporan Penelitian Perikanan Laut No. 1: 30-64.

Suman, A. 1990. Beberapa aspek biologi udang dogol (Metapenaeus ensis de Haan) di perairan pantai selatan Jawa. Jurnal Lingkungan dan Pembangunan: 128-134.

Suman, A. 1992. Dinamika udang dogol (Metapenaeus ensis de Haan) di perairan pantai selatan Jawa. Prosiding Seminar Ekologi Laut dan Pesisir I: hal. 64-71.

Suman, A. 2003. Pola pemanfaatan sumber daya udang dogol (Metapenaeus ensis de Haan) secara berkelanjutan di perairan Cilacap dan sekitarnya. Disertasi Doktor pada Sekolah Pasca Sarjana, IPB, Bogor.

Udupa, K. S. 1986. Statistical method of estimating the size at first maturity in fishes. Fishbyte 4 (2): 810. ICLARM. Metro Manila.

Van Zalinge, N.P. \& N. Naamin. 1975. The Cilacap based trawl fishery for shrimp along the south coast of Java. Laporan Penelitian Perikanan Laut No. 2: 1-15. 


\title{
UKURAN PERTAMA KALI MATANG KELAMIN, MUSIM PEMIJAHAN, DAN PARAMETER PERTUMBUHAN UDANG DOGOL (Metapenaeus ensis de Haan) DI PERAIRAN CILACAP DAN SEKITARNYA
}

\author{
Ali Suman") dan Mennofatria Boer")
}

\begin{abstract}
ABSTRAK
Penelitian dilakukan untuk mengkaji beberapa aspek dinamika populasi udang dogol (Metapenaeus ensis de Haan) di perairan Cilacap dan sekitarnya. Penelitian dilakukan dengan metode survei di perairan Cilacap dan sekitarnya dari bulan Mei 2001 sampai dengan bulan April 2002. Hasil penelitian menunjukkan bahwa ukuran pertama kali matang kelamin udang dogol adalah pada panjang karapas $31,80 \mathrm{~mm}$ dan udang memijah sepanjang tahun dengan puncaknya pada bulan September. Persamaan pertumbuhan von Bertalanffy udang jantan: $L t=41,50\left[1 e^{-1,49(t+0,03)}\right]$ dan udang betina: $L t=52,20\left[1-e^{-1,52(t+0,023)}\right]$.
\end{abstract}

\section{ABSTRACT: Size at first maturity, spawning season and growth parameters of endeavour shrimp (Metapenaeus ensis de Haan) in Cilacap and adjacent waters. By: Ali Suman and Mennofatria Boer}

The objective of this research is to study the population dynamic aspects of endeavour shrimp (M. ensis de Haan) in Cilacap and adjacent waters. This research was conducted from May 2001 to April 2002 with survey method. Results show that the size at first maturity of endeavour shrimp ( $\boldsymbol{M}$. ensis de Haan) was 31.8 $\mathrm{mm}$ in carapace length and spawned throughout the year with the peak spawning season in September. The von Bertalanffy growth equation of male endeavour shrimp is $L t=41,5\left(1-\theta^{-1,49(t+0,03)}\right)$ and female is $L t=52,2[1$ $\left.e^{-1,52(t+0,023)}\right]$.

\section{KEYWORD: first maturity, spawning season, growth parameter, endeavour shrimp, Cilacap}

\section{PENDAHULUAN}

Udang dogol (Metapenaeus ensis de Haan) merupakan jenis udang yang termasuk ke dalam famili Penaeidae yang dapat dibedakan dengan jenis udang lainnya oleh 2 ciri utama yaitu pinggir kulit bagian depan pada segmen kedua ditutupi oleh kulit pada segmen pertama dan tiga kaki jalan pertama (periopod) mempunyai capit (chelae) yang hampir sama besarnya (Naamin, 1984). Kelompok udang dogol umumnya berwarna putih kecoklatan atau hijau kemerahan dan bagi yang hidup di daerah pasang surut dan tambak berwarna gelap merata. Rostrum berbentuk lurus dan agak mengarah ke atas, bergerigi tipis hanya pada bagian atas dengan rumus 6-9/0, permukaan tubuhnya kasar (Racek \& Dall, 1965). Udang dogol dicirikan oleh rostrum lurus agak ke atas dengan rumus $9 / 0$. Warna biasanya coklat sampai merah jambu cerah, antena merah cerah, kaki merah jambu sampai merah dan kadang-kadang bergaris serta uropod merah. Udang dogol dapat mencapai panjang total $16 \mathrm{~cm}$ bagi udang betina serta $13 \mathrm{~cm}$ untuk udang jantan (Dall et al., 1990).

Udang dogol merupakan salah satu udang ekonomis penting di perairan Cilacap dan sekitarnya. Kontribusi produksinya mendominasi rata-rata sekitar $51 \%$ dari produksi udang Penaeid setiap tahunnya (Suman, 2003). Sedangkan pemanfaatannya sudah lama dilakukan, tetapi secara komersil baru dimulai pada tahun 1966, dengan mulai berkembangnya perikanan trawl untuk menangkap udang (Naamin,
1972 \& Gunadi, 1981). Sejak saat itu perkembangan pemanfaatan udang sangat intensif dan meningkat setiap tahun akibat bertambahnya armada penangkapan dan angkatan kerja (Van Zalinge \& Naamin, 1975; Naamin, 1978). Mengingat tingginya intensitas penangkapan udang dogof di perairan Cilacap pada akhir-akhir ini, yang dilakukan setiap hari sepanjang tahun, maka dikhawatirkan pemanfaatannya akan mengancam kelestarian dan keberlanjutan pemanfaatan sumber daya udang dogol. Untuk mencegah terjadinya hal tersebut dan agar pemanfataannya berada dalam keadaan yang rasional, maka diperlukan masukan dari hasil penelitian terutama dinamika populasi untuk mendasari pengelolaannya.

Tulisan ini membahas hasil penelitian tentang beberapa aspek dinamika populasi udang dogol di perairan Cilacap dan sekitarnya yang meliputi ukuran pertama kali matang kelamin, musim pemijahan, dan parameter pertumbuhan. Hasil penelitian diharapkan dapat digunakan sebagai bahan masukan untuk tujuan pengelolaan dan dasar bagi penelitian selanjutnya.

\section{BAHAN DAN METODE}

Penelitian didasarkan pada data frekuensi panjang karapas udang dogol hasil dari pengambilan contoh di TPI Pelabuhan Perikanan Samudera Cilacap (PPSC), yang merupakan tempat pendaratan udang utama di perairan Cilacap dan sekitarnya (Gambar

\footnotetext{
.. Peneliti pada Balaj Riset Perikanan Laut, Jakarta

-) Staf Pengajar pada Fakultas Perikanan dan Ilmu Kelautan IPB, Bogor
} 


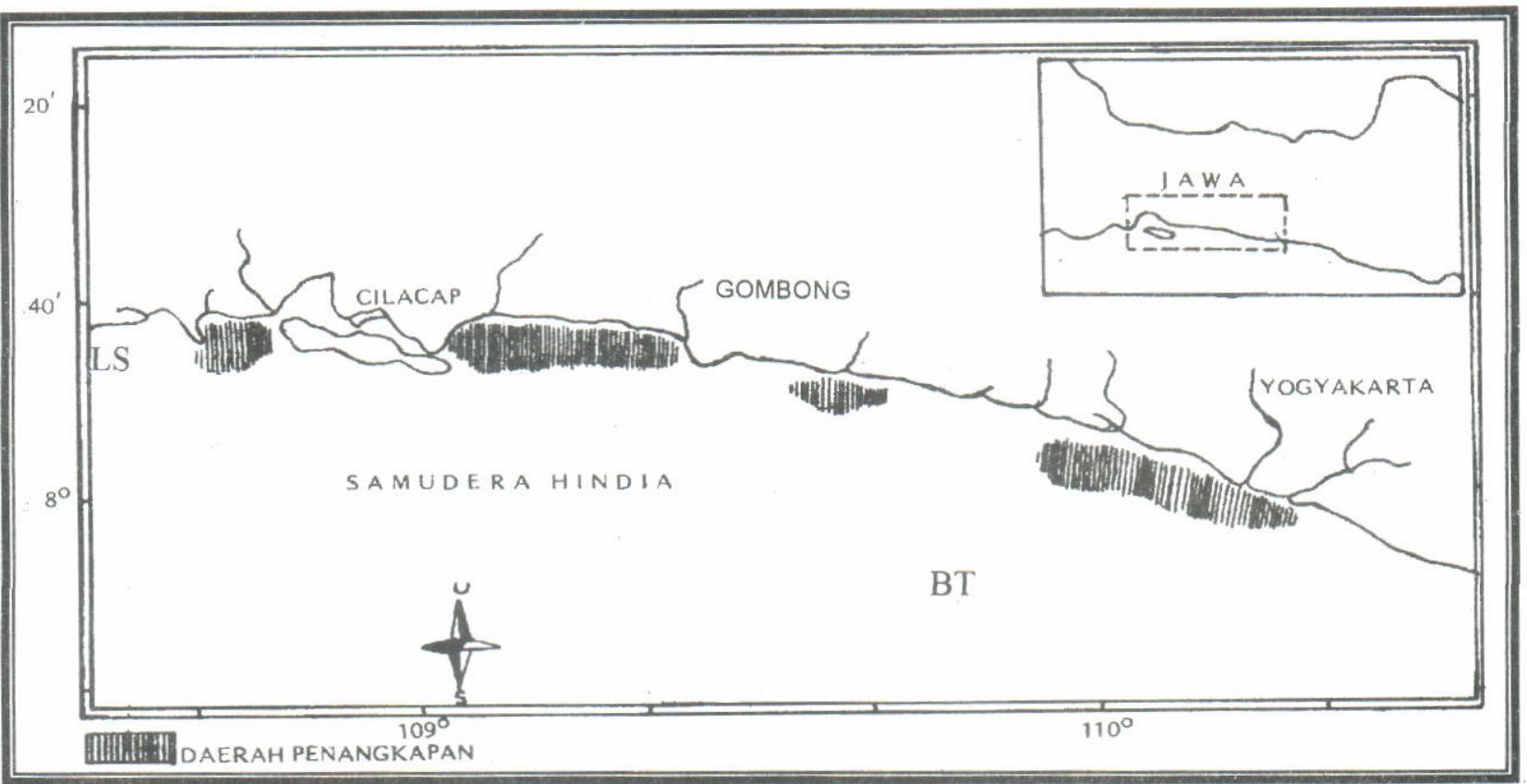

Gambar 1

Daerah penangkapan udang dogol (Metapenaeus ensis de Haan) di perairan Cilacap dan sekitarnya.

Figure 1. Fishing ground of endeavour shrimp (Metapenaeus ensis de Haan) in Cilacap and adjacent waters.

1). Penelitian dilakukan dari bulan Mei 2001 sampai dengan bulan April 2002. Pengamatan biometrik udang yang dilakukan meliputi pengukuran panjang karapas, jenis kelamin, dan tingkat kematangan kelamin.

Pendugaan ukuran udang pertama kali matang kelamin dilakukan menurut metode SpearmanKarber (Udupa, 1986) dan parameter pertumbuhan ( $K$ dan $L \infty$ ) dianalisis dengan metode ELEFAN (Sparre \& Venema, 1992; Gayanilo et al., 1993), sementara itu laju kematian total $(Z)$ diduga dengan metode catch curve (Sparre \& Venema, 1992). Laju kematian alamiah (M) diduga dengan menggunakan rumus empiris Pauly (1985) sebagai berikut:

$\log M=-0,0066-0,2790 \log L o 0+0,6543 \log K+0,4534$ $\log T$

Laju kematian karena penangkapan (F) dihitung dengan rumus: $\mathrm{F}=\mathrm{Z}-\mathrm{M}$ dan to dianalisis dengan menggunakan rumus empiris Pauly (Sparre \& Venema, 1992; Pauly, 1985).

\section{HASIL DAN BAHASAN}

\section{Ukuran Pertama Kali Matang Kelamin dan Musim Pemijahan}

Ukuran udang pada saat kematangan penting artinya dalam pengelolaan perikanan mengingat bahwa eksploitasi harus membiarkan sejumlah tertentu induk-induk ikan (udang) yang mempunyai ukuran sama atau lebih dari ukuran tersebut pada saat mencapai kematangan (Sudjastani, 1974). Pada umumnya udang betina mengalami kematangan kelamin pada ukuran yang lebih besar daripada udang jantan (Martosubroto, 1978).

Penyebaran persentase banyaknya udang dogol yang matang kelamin pada berbagai ukuran disajikan pada Tabel 1.

Selanjutnya dengan menggunakan metode Spearman-Karber (Udupa, 1986), didapatkan ukuran udang dogol pertama kali matang kelamin pada panjang karapas $31,8 \mathrm{~mm}$. Dibandingkan dengan udang dogol dari periode penelitian sebelumnya di perairan Cilacap, ternyata mengalami lebih awal ratarata kematangan gonadnya (panjang karapas 36,8 $\mathrm{mm}$ ), tetapi lebih lambat bila dibandingkan dengan keadaan di perairan Tanjung Krawang (panjang karapas $20 \mathrm{~mm}$ ) (Martosubroto, 1978; Suman, 1990). Adanya perbedaan rata-rata ukuran pertama kali matang pada berbagai perairan dipengaruhi oleh ketersediaan makanan dan kondisi lingkungan lainnya, seperti suhu dan salinitas. Menurut Udupa (1986), ukuran pada saat kematangan bervariasi di antara spesies dan di dalam spesies yang sama.

Selanjutnya untuk mengetahui musim pemijahan udang di suatu perairan dapat diteliti melalui pengamatan terhadap penyebaran densitas telur atau dapat pula melalui pengamatan terhadap kematangan kelamin udang betina di perairan tersebut (Martosubroto, 1978). Selama penelitian ini diperoleh udang betina yang belum matang gonad sebanyak 888 ekor $(41 \%)$ dan yang matang kelamin sebanyak 1.270 ekor (59\%). Pada Tabel 2 diterakan persentase 
Tabel 1. Sebaran frekuensi (\%) udang dogol (Metapenaeus ensis de Haan) yang matang kelamin pada berbagai ukuran di perairan Cilacap dan sekitarnya

Table 1. Frequency distribution (\%) of mature endeavour shrimps (Metapenaeus ensis de Haan) maturing at difference sizes in Cilacap and adjacent waters

\begin{tabular}{cc}
\hline Panjang karapas/Carapace length $(\mathrm{mm})$ & Persentase $(\%)$ \\
\hline 24 & 5 \\
26 & 6 \\
28 & 9 \\
30 & 16 \\
32 & 41 \\
34 & 57 \\
36 & 62 \\
38 & 70 \\
40 & 80 \\
42 & 100 \\
44 & 100 \\
46 & 100 \\
48 & 100 \\
50 & 100 \\
\hline
\end{tabular}

Tabel 2. Sebaran frekuensi (\%) udang dogol (Metapenaeus ensis de Haan) menurut tingkat kematangan gonad di perairan Cilacap dan sekitarnya

Table 2. Frequency distribution (\%) of endeavour shrimps (Metapenaeus ensis de Haan) following to the gonad maturity in Cilacap and adjacent waters

\begin{tabular}{cccc}
\hline \multirow{3}{*}{ Tahun/Year } & Bulan/Month & \multicolumn{2}{c}{ Tingkat kematangan/Gonad maturity stage } \\
\cline { 2 - 4 } & Mei & $\begin{array}{c}\text { Belum matang/ } \\
\text { Immature }\end{array}$ & $\begin{array}{c}\text { Matang/ } \\
\text { Mature }\end{array}$ \\
\hline \multirow{4}{*}{2001} & Juni & 41 & 59 \\
& Juli & 39 & 61 \\
& Agustus & 34 & 66 \\
& September & 45 & 55 \\
& Oktober & 14 & 86 \\
& Nopember & 53 & 47 \\
& Desember & 62 & 38 \\
& Januari & 46 & 54 \\
& Pebruari & 49 & 51 \\
& Maret & 38 & 62 \\
& April & 45 & 55 \\
\hline
\end{tabular}

udang dogol betina yang berada dalam tingkatan matang kelamin di perairan Cilacap dan sekitarnya.

Keadaan daerah tropis dengan suhu perairan yang relatif tidak berfluktuasi mendorong udang untuk mampu memijah sepanjang tahun, walaupun demikian tentu ada puncak-puncak di mana sebagian besar lebih senang memijah. Adanya larva-larva yang masuk ke tambak-tambak di Jepara sepanjang tahun menguatkan hal tersebut (Prawirodihardjo et al., 1975). Di perairan Cilacap terlihat udang dogol memijah sepanjang tahun dengan puncaknya bulan September (Tabel 3). Dengan tertangkapnya udang-udang dogol yang matang kelamin pada berbagai ukuran, mulai dari ukuran yang relatif kecil (panjang karapas $24 \mathrm{~mm}$ ) sampai yang besar (panjang karapas $50 \mathrm{~mm}$ ), memberikan suatu petunjuk bahwa udang dogol tersebut mampu bertelur lebih dari satu kali dalam hidupnya.

\section{Parameter Pertumbuhan}

Pada dasarnya program ELEFAN digunakan untuk menginterpretasikan data frekuensi panjang karapas dengan cara melacak pergeseran modus sebaran frekuensi panjang karapas dalam suatu urutan waktu (time series) yang dicocokkan dengan kurva von Bertalanffy. Kurva yang melalui modus paling banyak akan menggambarkan pola pertumbuhan (Sparre \& Venema, 1992).

Dengan merunut data frekuensi panjang karapas dari bulan ke bulan (Gambar 2) diperoleh laju pertumbuhan $(K)$ udang dogol jantan sebagai 1,49 per tahun dan panjang karapas maksimum (Loo) sebagai $41,5 \mathrm{~mm}$, sedangkan untuk udang dogol betina nilai laju pertumbuhannya $(K)$ adalah 1,52 per tahun dan panjang karapas maksimum $\left(L^{\infty}\right)$ adalah $52,2 \mathrm{~mm}$. 

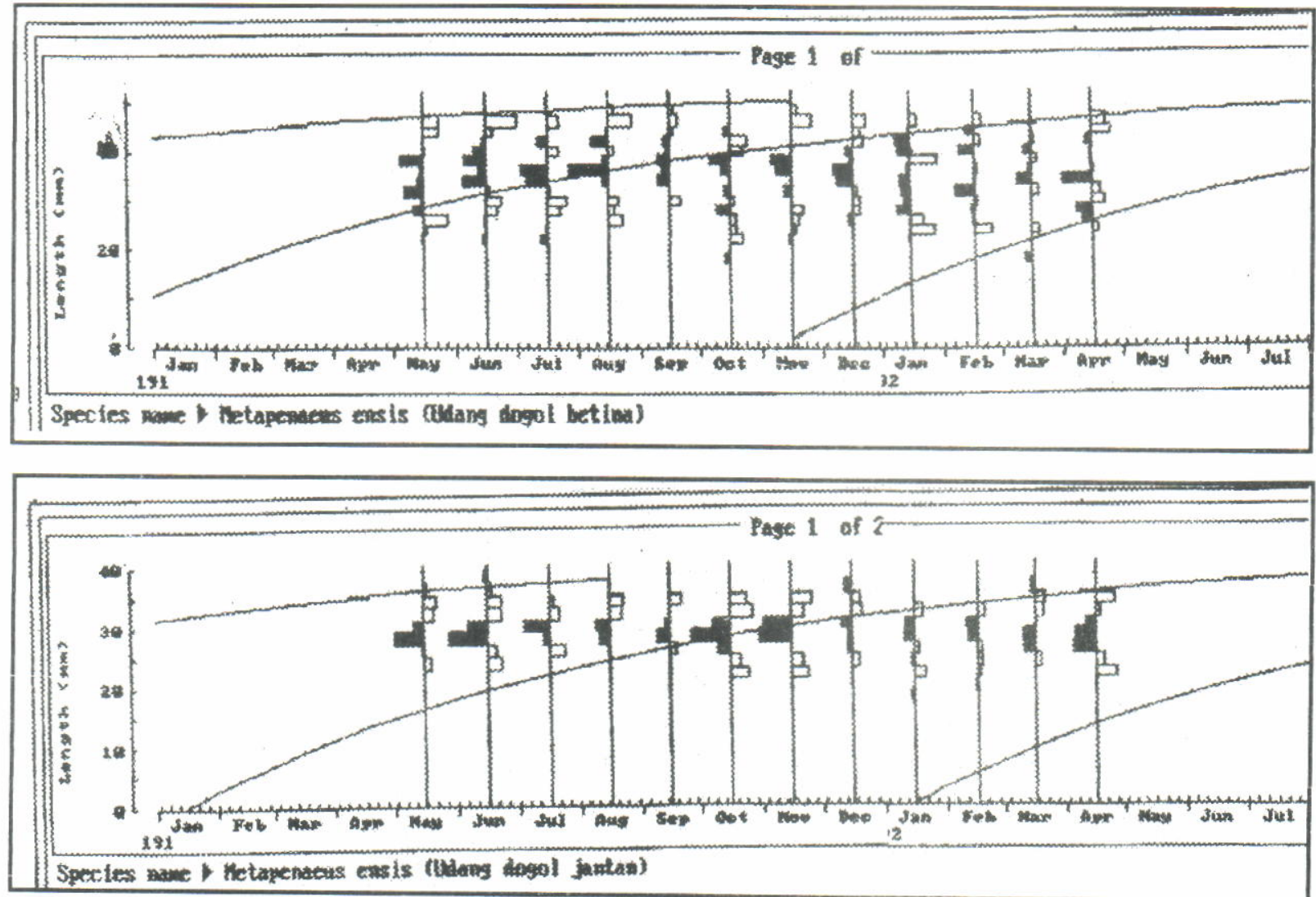

Gambar 2

Figure 2. Carapace length frequency distribution of endeavour shrimp (Metapenaeus ensis de Haan)

Penyebaran frekuensi panjang karapas udang dogol (Metapenaeus ensis de Haan) yang dirunut dengan ELEFAN. by using ELEFAN method.

Laju pertumbuhan $(K)$ udang dogol jantan dan betina hasil penelitian terlihat lebih kecil bila dibandingkan dengan laju pertumbuhan udang dogol di perairan yang sama pada periode sebelumnya yaitu 1,61 per tahun untuk udang dogol betina dan 1,63 per tahun untuk udang dogol jantan (Suman, 1992), tetapi lebih besar bila dibandingkan dengan nilai $\mathrm{K}$ udang dogol (Metapenaeus affinis) di perairan Versoba, India yang sebesar 1,20 per tahun (Pauly et al., 1984). Adanya perbedaan laju pertumbuhan udang ini pada berbagai perairan kemungkinan dipengaruhi oleh ketersediaan makanan dan kondisi lingkungan. Nilai K udang dogol betina juga terlihat lebih besar dari nilai $\mathrm{K}$ udang jantan dan hal ini tercermin juga dalam hasil tangkapan, di mana ukuran udang dogol betina didapatkan selalu lebih besar dari udang jantan. Dall et al., (1990) menyatakan bahwa pertumbuhan udang betina selalu lebih cepat dari udang jantan dan biasanya pada umur yang sama selalu ditemui udang betina lebih besar dari udang jantan.

Dari nilai $K$ yang lebih besar dari satu menunjukkan bahwa udang dogol mempunyai pertumbuhan yang cepat (Gulland, 1983; Naamin, 1984). Cepatnya pertumbuhan dan pendeknya umur udang dogol menunjukkan bahwa laju kematian cukup tinggi. Hal tersebut memberikan peringatan agar memperhatikan pemanfaatan sumber daya udang dogol secara berkelanjutan. Sehubungan dengan umur, laju pertumbuhan, dan kematian yang perlu diperhatikan adalah kapan waktu yang tepat untuk menangkapnya, baik ditinjau dari sumber dayanya sendiri maupun dari segi ekonominya? Kalau terlambat menangkap udang tersebut akan mati percuma, sedangkan kalau terlalu cepat di tangkap secara ekonomi dan kelestarian sumber daya juga kurang menguntungkan. Dengan kasus pertumbuhan yang relatif cepat, penundaan penangkapan beberapa bulan saja akan menghasilkan jumlah individu yang berlipat ganda. Selain itu kalau udang yang berusia muda terlalu banyak ditangkap akan terjadi kelebihan tangkap pertumbuhan (growth over-fishing). Hal ini juga menyebabkan kelebihan tangkap penambahan baru (recruitmen overfishing), karena udang-udang muda yang belum sempat dewasa dan bertelur sudah tertangkap terlebih dahulu sehingga hilang kesempatannya untuk penambahan baru (recruitment).

\section{Laju Kematian}

Bila data frekuensi panjang dan parameterparameter pertumbuhan tersedia, maka pendekatan langsung untuk menduga laju kematian total (Z) adalah dengan membuat kurva hasil tangkap (catch curve), yaitu dengan memplotkan logaritma (natural) jumlah udang pada umur tertentu terhadap umurnya. 